\title{
Nyadran tradition as an effort to preserve Jenon's water resources and its socio-cultural values
}

\author{
W.D. Sulistyo* \& N. Sadiyah \\ Universitas Negeri Malang, Malang, Indonesia
}

\begin{abstract}
Javanese people appreciate local culture or wisdom. Especially if it is something that is disputed. One example of a community that still preserves ancestral culture is the people of Gunung Ronggo village, Tajinan subdistrict, Malang regency. The Community considers that the existence of Jenon water springs as sacred and worthy of preservation. A variety of traditions are done, one of them is Nyadran tradition which is routinely implemented in the Jenon water springs area. Not only as a preservation of the place, Nyadran tradition is also preserved because it contains positive social and cultural values. This is what caused the people of Gunung Ronggo village to preserve Nyadran's tradition as a form of preservation of the Jenon spring source.
\end{abstract}

Keywords: water, Sumber Jenon, sacred, belief, preservation, tradition, Nyadran

\section{INTRODUCTION}

Sumber Jenon is one of the local tourist attractions in Gunung Ronggo Village, T Crafts District, Malang Regency. This source is one of the water sites in the Greater Malang area (Sulistyo et al. 2020). Malang is an administrative area in East Java which has many historical sites (Sayono et al. 2019; Sulistyo et al. 2020) This place is actually a natural spring which then forms a pool of water. Unmitigated, this circular pool of water from Jenon Source measures about $650 \mathrm{~m}$ with a depth of up to $7 \mathrm{~m}$. At the bottom of this pool, there is a large Jenu tree that collapsed decades ago. The local people believe that this tree is not an ordinary tree, but a sacred tree which then collapses and creates a mysterious spring. The spring is now called Sumber Jenon and is believed to have many benefits by the local community until now.

As a sacred place, of course Sumber Jenon is then preserved by the local community. Conservation itself is a process undertaken to manage natural resources, especially those that have certain benefits so that their authenticity is maintained at any time. This also shows that the role of the local community in the preservation of Sumber Jenon is very high. Now, Sumber Jenon spring is one of the tourist destinations for local and foreign visitors (Orbasli, 2002; Soeroso \& Susilo, 2014).

One example of a form of preservation is the implementation of traditions. Tradition itself is a habit or custom carried out by the community from generation to generation from ancestors to today's society. Various traditions are also often held by the people of Gunung Ronggo Village as a form of respect for the sacredness of the Sumber Jenon area. One of the traditions routinely carried out at the Sumber Jenon spring complex is the Nyadran tradition. This tradition has always been celebrated jointly by all the villagers of Gunung Ronggo until now (Indonesia, 2002; Suwito et al. 2015).

The tradition of Nyadran is not without reason. There are several reasons why the people of Gunung Ronggo Village continue to maintain this tradition. One of them is the socio-cultural values contained in the Nyadran tradition. This tradition is an ancestral heritage that has primacy values

${ }^{*}$ Corresponding Author 
(Sulistyo, 2016; Sulistyo \& Pamungkas, 2020). As part of the millennial generation, cultivating characters such as socio-cultural values are very important. As time goes by, Indonesian people have begun to abandon the values of life which will gradually destroy this nation. Because the Nyadran tradition is a tradition that still contains efforts to instill character for the people of Gunung Ronggo Village, this tradition is still carried out regularly today (Yunus, 2013).

\section{METHODS}

The method used in the research is a qualitative research method. In the implementation process, the researcher collected data directly in the field with several activities, namely direct observation, interviews and documentation (Creswell \& Creswell, 2017; Denzin \& Lincoln, 2008), described in more detail below. This stage is carried out by the researcher in order to see firsthand the condition of the object under study. In this case the object in question is the Sumber Jenon tourist area which is located in Gunung Ronggo Village, T Crafts District, Malang Regency. This observation was carried out for one day on July 19, 2020. Researchers came directly to the observation area and noted important and interesting points in the Sumber Jenon area. The resource persons selected by the researcher in the interview process were Mr. Sholeh (28 years) as the manager of the Sumber Jenon tourist area and Mr. Aspuri (56 years) as the Head of Gunung Ronggo Village. Several things discussed with the manager of the tourist attractions and the Head of Gunung Ronggo Village were related to the conservation and management of Sumber Jenon

\section{RESULTS AND DISCUSSION}

\subsection{Site description}

The pool in the Sumber Jenon area is divided into two types, the main pool which contains the roots of the Jenu tree, and a small pool for small children to swim in. Based on research results from Asmaranto (Sulistyani \& Irianto, 2018), the size of the main pond at Sumber Jenon is estimated to have an area of $649.1 \mathrm{~m}^{2}$ with a depth of up to $7 \mathrm{~m}$. In the main pool, it is also divided into two parts. One part that has a depth of up to $4 \mathrm{~m}$ is usually used for swimming for visitors, while the other part of the pool has a depth of up to $7 \mathrm{~m}$ and it is not allowed for visitors to swim in this area. The barrier for the two parts of the pool is a wooden bridge that visitors can walk through to get to the other side of the pond.

Apart from being a pool, the Sumber Jenon area is also surrounded by forests filled with very dense shady trees. Large trees such as Mahogany, Gondang, Banyan trees and so on still stand firmly around the pond. This makes the Jenon Source complex a beautiful complex that is not exposed to too much sunlight. Water sources are always considered by the local community as a sacred and sacred place, as well as for the people around the Sumber Jenon tourist spot, they consider this place sacred. There are still places for offerings around the pool area, used for visitors who want to pray or whoever has an interest.

According to Mr. Sholeh (28 years) as the manager of Sumber Jenon, before February 2019, the Sumber Jenon area was only an ordinary spring and not a tourist spot. This means that this place is not yet managed. This area is a village asset that is visited by the surrounding community. Several years ago, even if there was a large use, this place was only used as a gathering place for celebrations for local residents. Usually, every Raya day there is a thanksgiving in this area. Only in 2019, Sumber Air Jenon began to be managed as a tourist spot under the authority of Village-Owned Enterprises (BUMDes). As a place that has the potential to become an asset to the village's pride, of course many things are done by the community to conserve Sumber Jenon. One of the traditions that is still being carried out to preserve Sumber Jenon is the Nyadran tradition. 


\subsection{Nyadran tradition}

Nyadran is one of the traditions that developed in Java since the past. During Hindu-Buddhist times, the Nyadran Tradition was known as the Craddha tradition, a form of ceremony to honor ancestors by bringing offerings and chanting praises during the implementation process. This Craddha tradition has at least been carried out since the Majapahit era, namely at the end of the 13th century. Meanwhile, during the Islamic period, the Nyadran tradition was also continued and continued to be carried out by including prayers from the Al-Quran. In fact, there are many sources that describe what the true function of Nyadran is. Sometimes, this tradition is also associated with the tradition of cleaning the tomb before Ramadan, the tradition of earth alms, or other traditions. Some people also believe that the Nyadran tradition is the result of a tradition of acculturation between Islam and Javanese culture. In essence, the Nyadran tradition in each place has a different function (Saddhono et al. 2019; Sih et al. 2018).

One group that still inherits this tradition is the people of Gunung Ronggo Village, T Crafts District, Malang Regency. In this area, there is one sacred place that is still sacred by the local community. That place is the source of Jenon. As a sacred place, of course the local people often hold events in the Sumber Jenon complex area. One of them is the Nyadran tradition. This tradition is carried out every Selo month (Dzulhijjah) every year. This means that this tradition is celebrated as a New Year's anniversary celebration. In addition, people often carry out the Nyadran tradition on every holiday.

Local people will come together to the Sumber Jenon spring area, bringing food which is commonly called encek-encek. While being led by traditional leaders and local religious leaders, the people of Gunung Ronggo Village will pray together hoping for the safety of the village and as an expression of gratitude. Then, people will exchange food before returning to their respective homes. In addition to the Nyandran tradition, there is also a local tradition called Adat Kelapet. This tradition is the tradition of protecting the seeds of the farmers from the river in this village. Implemented before the farming season, in hopes that the harvest will run smoothly. This tradition is similar to the Wiwitan tradition in Sentong Hamlet, Karangduren Village, Pakisaji District, Malang Regency. The local village community will carry out the Wiwitan tradition to pray that the harvest will run smoothly (Interview with Rosi, 21 years).

\subsection{Socio-cultural values in the Nyadran tradition}

As a tradition that is still routinely carried out until now, it can be said that the Nyadran tradition has benefits that are felt by the people of Gunung Ronggo. As with other traditions, if at present a tradition has no functional value for the people who carry it out, then slowly the tradition will be abandoned. Seeing that the Nyadran tradition is still ongoing in Gunung Ronggo village, it means that the local community thinks that this tradition has many benefits. Some things that can be seen from this tradition are its benefits in the social and cultural fields.

The Nyadran tradition in Gunung Ronggo village is also inseparable from the social and cultural values that make the local community still practice it today. Research was conducted to find out what social and cultural values are contained in these traditions. This research was conducted by making direct observations to the object of research, in this case the Village of Gunung Ronggo, and interviews with the Head of Gunung Ronggo Village and the Manager of the Sumber Jenon Spring Area. The results of this study are as follows:

First, the social values that exist in the Nyadran tradition. Social values can be interpreted as relationships between individuals. This relationship certainly has a positive impact between each other that makes each individual feel comfortable to continue the tradition in question. Social values also have many characteristics, including social interaction between communities, humanizing human nature, supporting harmony, and so on. In addition, social values also have a function as a unifying individual (Mustanir \& Razak, 2017; Regan, 2000; Rohman \& Hairudin, 2018). The social values that can be seen from the Nyadran tradition include the value of harmony and mutual cooperation. The value of harmony is not only an obligation for the Indonesian people, but also 
something that must be upheld in social life. In order to lead a harmonious life, each individual must also have a high awareness. This can be seen from the implementation of the Nyadran tradition in Gunung Ronggo Village. When this tradition took place, all village communities, whether young, old, male, female, Muslim, non-Muslim, all participated in the process of implementing Nyadran. Since ancient times, all the villagers of Gunung Ronggo have never been burdened by this tradition, they have been very active in participating in every implementation. This automatically shows harmony in the Gunung Ronggo community (Harahap, 2011).

Furthermore, there is the value of mutual cooperation. The value of mutual cooperation is also a very important value for social life. Mutual cooperation is very much needed for the welfare and advancement of society. By increasing the nature of mutual cooperation, at least this can also prevent conflict within the community. The value of mutual cooperation can also be shown through activities that are often carried out together, such as taking care of funerals, weddings, almsgiving the earth, celebrating holidays, and so on. In terms of this Nyadran tradition, the people of Gunung Ronggo show cooperative behavior in terms of big day celebrations. Together they coordinate how to carry out the Nyadran tradition with all kinds of preparations. Seeing that this tradition has been carried out for a long time and are still ongoing today proves that the people of Gunung Ronggo have practiced mutual cooperation from the past until now (Irfan, 2017; Korniawan, 2017; Slikkerveer, 2019).

Second, cultural values are also inseparable from the Nyadran tradition. This is because the Nyadran tradition is a tradition carried out by Javanese people since ancient times. Javanese people are known to highly uphold Javanese culture. Whatever culture was carried out by the ancestors, will still be preserved until now if it is felt that it provides benefits for them. Culture, tradition and Java cannot be separated. Indeed, the Javanese people cannot be separated from such traditions or beliefs. It can be said that the core of Javanese culture is belief itself. Therefore, the Javanese people tend to highly uphold existing traditions or myths (Mu'adi \& Sofwani, 2018; Nawafil \& Tiara, 2016).

Just like the Nyadran tradition for the people of Gunung Ronggo. This tradition is also upheld by all people as a form of respect for ancestral culture. Of course, the application of the Nyadran tradition has changed its function from what was previously a form of respect for Hindu Buddhists, to now a form of respect and great ceremony for the people of Gunung Ronggo who are predominantly Muslim. This proves that today, the Javanese people still value their ancestral culture, which can be proven by their availability to carry out various kinds of existing cultures.

\section{CONCLUSIONS}

The people of Gunung Ronggo Village are one of the groups of people who still hold sacred places. In this case the Sumber Jenon spring. Because this area is an area that is considered sacred, the villagers of Gunung Ronggo often hold big celebrations or traditions in the Sumber Jenon spring area. One tradition that is still very often carried out is the Nyadran tradition. Tradition is a form of tradition to honor ancestors by bringing food together and praying together in the Sumber Jenon area. This celebration is usually done in 1 Suro or other big events. Not only to preserve the holy spring of Sumber Jenon, the Nyadran tradition also has many social and cultural values. These values are always emphasized by the people of Gunung Ronggo Village to maintain their traditions. The examples of the values in question are the values of mutual cooperation, harmony and culture.

\section{REFERENCES}

Creswell, J.W. \& Creswell, J.D. 2017. Research design: Qualitative, quantitative, and mixed methods approach. Sage publications.

Denzin, N.K. \& Lincoln, Y.S. 2008. Introduction: The discipline and practice of qualitative research.

Harahap, S. 2011. Teologi kerukunan. Kencana. 
Indonesia, T.R.K.B.B. 2002. Kamus besar bahasa Indonesia. Jakarta: Balai Pustaka.

Irfan, M. 2017. Metamorfosis gotong royong dalam pandangan konstruksi sosial. Prosiding Penelitian dan Pengabdian Kepada Masyarakat 4(1): 1-10.

Korniawan, R. 2017. Exploring the cultural values of "saemaul undong" and "gotong royong" as the development of an anti-corruption culture: socio-economic studies in East Asia and Southeast Asia. Asia Pacific Fraud Journal 3(2): 319-327.

Mu'adi, S. \& Sofwani, A. 2018. Acculturation of Islam and Javanese culture in public servant ethics. El Harakah 20(2): 233.

Mustanir, A. \& Razak, M.R.R. 2017. Nilai sosial budaya pada partisipasi masyarakat etnik Towani Tolotang dalam musyawarah rencana pembangunan. Prosiding Konferensi Nasional Ke-6 Asosiasi Program Pascasarjana Perguruan Tinggi Muhammadiyah Aisyiyah (APPPTMA): 1-7.

Nawafil, M.I. \& Tiara, N. 2016. Islam And Cultures: Java-Acculturated Islam in Islamic perspective. International Conference on Social Politics.

Orbasli, A. 2002. Tourists in historic towns: Urban conservation and heritage management. Taylor \& Francis.

Regan, P.M. 2000. Legislating privacy: Technology, social values, and public policy. Univ of North Carolina Press.

Rohman, M. \& Hairudin, H. 2018. Konsep tujuan pendidikan islam perspektif nilai-nilai sosial-kultural. Al-Tadzkiyyah: Jurnal Pendidikan Islam 9(1): 21-35.

Saddhono, K. et al. 2019. Local wisdom on Nyadran tradition in Sragen Regency. INCOLWIS 2019: Proceedings of the 2nd International Conference on Local Wisdom, August 29-30, 2019. Padang: EAI.

Sayono, J. et al. 2019. Situs sejarah Malang Raya masa Islam dan kolonial. Malang: Jurusan Sejarah FIS UM.

Sih, Y.N. et al. 2018. Religious value in nyadran ceremony in Ngepringan village, Sragen. El Harakah 20(2): 155.

Slikkerveer, L.J. 2019. Gotong royong: An indigenous institution of communality and mutual assistance in Indonesia. In Integrated Community-Managed Development. Springer.

Soeroso, A., \& Susilo, Y.S. 2014. Traditional Indonesian gastronomy as a cultural tourism attraction. Editorial Board.

Sulistyani, K.F. \& Irianto, D.B. 2018. Studi pemanfaatan air sumber Jenon untuk pemenuhan kebutuhan air irigasi dan domestik di kecamatan tajinan kabupaten malang. Reka Buana: Jurnal Ilmiah Teknik Sipil Dan Teknik Kimia 3(2): 137-142.

Sulistyo, W.D. et al. 2020. Jesiamar: Jelajah situs Air Malang Raya. Malang: Fakultas Ilmu Sosial.

Sulistyo, W.D. et al. 2020. Jejak sejarah Malang Raya. Malang: CV. Bintang Sejahtera.

Sulistyo, W.D. 2016. Pengembangan model pembelajaran sejarah berbasis nilai-nilai serat wicara keras untuk meningkatkan kemampuan berpikirkritis siswa sma insan cendekia al mujtaba sukoharjo. (Unpublished Thesis). Surakarta: Universitas Sebelas Maret.

Sulistyo, W.D. \& Pamungkas, O.Y. 2020. Pemanfaatan situs sejarah peradaban Islam di Kota Malang sebagai aktivitas belajar untuk menanamkan nilai karakter. AGASTYA: Jurnal Sejarah dan Pembelajaranya 10(1): 1-15.

Suwito, S. et al. 2015. Tradisi dan ritual kematian wong Islam Jawa. IBDA: Jurnal Kajian Islam dan Budaya 13(2): 6-25.

Yunus, R. 2013. Transformasi nilai-nilai budaya lokal sebagai upaya pembangunan karakter bangsa. Jurnal Penelitian Pendidikan 13(1): 67-79.

Yusof, A. 2016. Relasi Islam dan budaya lokal: Studi tentang tradisi Nyadran di Desa Sumogawe Kecamatan Getasan Kabupaten Semarang. IAIN Tulungagung Research Collections 4(1): 67299. 